\title{
Simultaneous occurrence of follicular lymphoma and mixed-cellularity Hodgkin's lymphoma: lymph node and extranodal involvement
}

\author{
Ocorrência simultânea de linfoma folicular e linfoma de Hodgkin celularidade mista: envolvimento nodal e \\ extranodal
}

Maria do Patrocínio F. Grangeiro'; Sílvia Maria M. Magalhães²; Francisco Valdeci A. Ferreira'; Francisco Dário Rocha Filho'

key words Composite lymphoma

Spleen

Lymph node

Follicular lymphoma

Hodgkin's lymphoma

\section{abstract}

An unusual and well-characterised case of composite lymphoma in the spleen and lymph node is presented. The simultaneous occurrence of mixed-cellularity Hodgkin's lymphoma (HL) and follicular non-Hodgkin's lymphoma (NHL) was demonstrated in a 66-year-old man admitted in our Service with anaemia, hepatosplenomegaly and multiple abdominal lymph nodes. The morphological study of the spleen and lymph node of the splenic hilum showed an infiltrate composed of two distinct neoplasias. The liver was involved by NHL infiltrate and the peripancreatic lymph node exhibited HL. The Reed-Sternberg (RS) cells expressed CD 15 and CD 30, whereas the NHL cells presented standard immunohistochemical features of follicular lymphoma. To our knowledge, this is the fifth case report of concurrent spleen involvement by composite lymphoma. The incidence, clinicopathological and immunohistochemical features of this rare association are discussed.
Os autores apresentam um caso raro e bem caracterizado de linfoma composto no baço e linfonodos. A ocorrência simultânea de um linfoma de Hodgkin e um linfoma não-Hodgkin foi demonstrada em um homem de 66 anos admitido com anemia, hepatosplenomegalia e múltiplos linfonodos abdominais. O estudo morfológico do baço e linfonodo do hilo esplênico mostrou infiltração por duas neoplasias distintas. O fígado estava envolvido por linfoma não-Hodgkin e o linfonodo peripancreático mostrava um linfoma de Hodgkin. As células de ReedSternberg (RS) expressaram CD 15 e CD 30, enquanto as células do linfoma não-Hodgkin apresentaram os aspectos imunoistoquímicos clássicos do linfoma folicular. Na literatura médica, este é o quinto caso descrito de envolvimento do baço por linfoma composto. A incidência, aspectos clínicos e imunoistoquímicos desta rara associação são discutidos. unitermos

Linfoma composto

Baço

Linfonodo

Linfoma folicular

Linfoma de Hodgkin 


\section{Introduction}

The simultaneous occurrence of two different subtypes of lymphoma within the same or in more than one anatomical site is defined as composite lymphoma. Composite lymphoma is rare and its incidence varies among the different types of lymphomas and depends on the number of anatomic sites studied at the time of diagnosis or during the course of the illness ${ }^{(5,13)}$. In some cases Hodgkin's lymphoma (HL) is associated with non-Hodgkin's lymphoma (NHL). The association of nonclassical $\mathrm{HL}$ and $\mathrm{NHL}$ is more common. This phenomenon occurs more frequently than it would be expected by chance, supporting the clonal relationship between the two tumours ${ }^{(6,7)}$. In most cases, however, the composite lymphoma is a combination of NHL of different histological types ${ }^{(3,5,7)}$. In these cases the immunophenotypic and genotypic analysis have indicated that the two histologic types are clonally related ${ }^{(3,7)}$. The most common anatomic site involved is the lymph node, although cases arising in extranodal sites have also been reported $^{(11)}$.

\section{Case report}

A 66-year-old man was admitted to the University Hospital because of asthenia, progressive paleness and weight loss. There was no history of fever, night sweat or any other systemic complaints. Physical examination revealed paleness and moderate hepatosplenomegaly. No peripheral lymphadenopathy was evident. Peripheral cell counts showed a red blood cell count of $3.2 \times 10^{12} / \mathrm{L}$, haemoglobin level of $8.4 \mathrm{~g} / \mathrm{dl}$, haematocrit $25 \%$, white blood cell count of $10.9 \times 10^{9} / \mathrm{L}$ and platelet count $297 \times 10^{9} / \mathrm{L}$. Alkaline phosphatase level was $460 \mathrm{U} / \mathrm{L}$ (normal range: 50 to $250 \mathrm{U} / \mathrm{L}$ ) and lactate dehydrogenase level was $563 \mathrm{U} / \mathrm{L}$ (normal range: 150 to $360 \mathrm{U} / \mathrm{L}$ ). An abdominal ultrasonographic study showed moderate liver enlargement and multiple retroperitoneal nodular images suggestive of lymph nodes. The patient underwent diagnostic laparotomy and splenectomy was performed along with biopsy of the liver, omentum and peripancreatic lymph nodes. The macroscopic examination revealed an enlarged spleen $(19 \times 16 \times 8 \mathrm{~cm})$ which weighed $900 \mathrm{~g}$. Sections of the spleen revealed a prominent white pulp and whitish well-delimited nodule next to the capsule, measuring $2 \mathrm{~cm}$ in diameter (Figure 1). Peripancreatic and splenic hilum lymph nodes were compact and whitish.

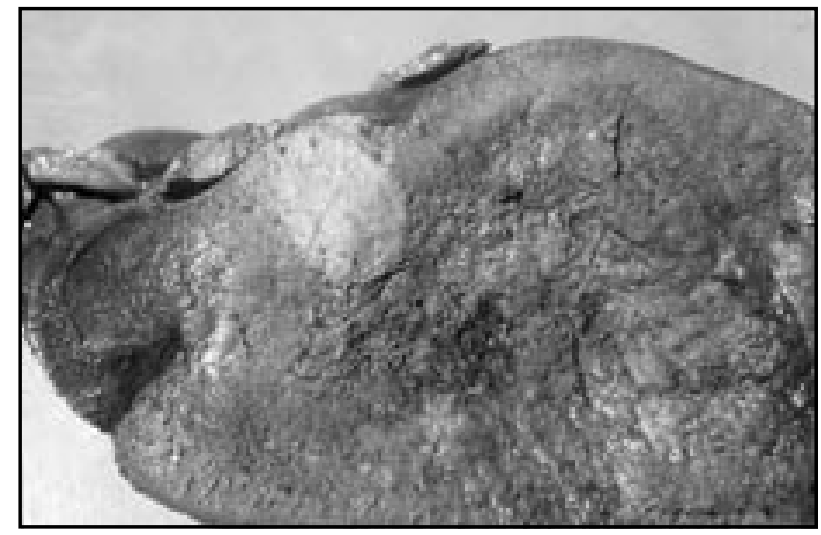

Figure 1 - Gross appearance of the spleen showing prominent white pulp and whitish well-delimited nodule next to the capsule

The histological analysis showed composite lymphoma in the spleen and lymph node of splenic hilum. The spleen exhibited a white pulp infiltrated by lymphoid neoplasia composed of a monotonous population of small cells consistent with follicular NHL (Figure 2A). The nodular pericapsular area showed occasional typical ReedSternberg (RS) cells against a background of lymphocytes, eosinophils, histiocytes, plasma cells; diagnosis of classical $\mathrm{HL}$ was made. The $\mathrm{HL}$ infiltration represented $10 \%$ of the spleen and was clearly distinct from the NHL component (Figure 2B). The lymph node of splenic hilum exhibited both diseases and the NHL and HL components were also in distinct areas from each other. The $\mathrm{HL}$ area infiltrated $40 \%$ of the lymph node.

Microscopic examination of the peripancreatic lymph node revealed a diffuse effacement of the architecture by HL. Extensive areas of fibrosis, foci of necrosis and numerous RS cells and variants, admixed with lymphocytes, eosinophils, histiocytes and plasma cells were seen. In the liver, infiltration of the portal space by small cell lymphoma, similar to that seen in the white pulp of the spleen, was evident (Figure 3A).

Immunohistochemical analysis, performed on formalinfixed paraffin-embedded sections by the PAP method, revealed that the small lymphoid-cells of the liver, spleen and lymph node of the splenic hilum expressed CD 45, $\mathrm{CD} 20$ and $\mathrm{BCl} 2$ (Figure 3B). The RS cells of spleen and lymph node exhibited expression of CD 15, CD 30 and LMP1/EBV (Table and Figure 4).

After a short-term follow-up, the disease evolved into septicaemia and the patient died 17 days after surgery, without having started chemotherapy. 


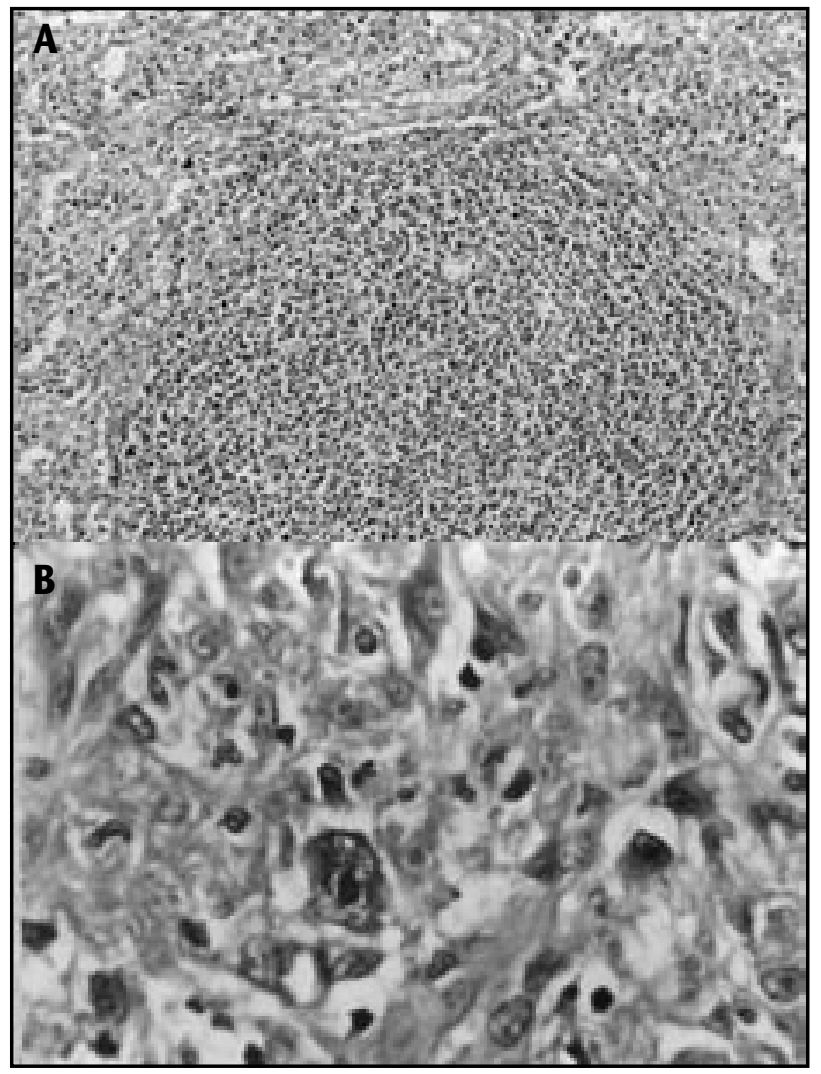

Figure 2 - A: Spleen showing white pulp infiltrated by small cell lymphoma (H\&E $200 x$ ). B: Spleen showing a mixed-cellularity Hodgkin's lymphoma, with RS cells and variants admixed with lymphocytes (H\&E $400 x$ )

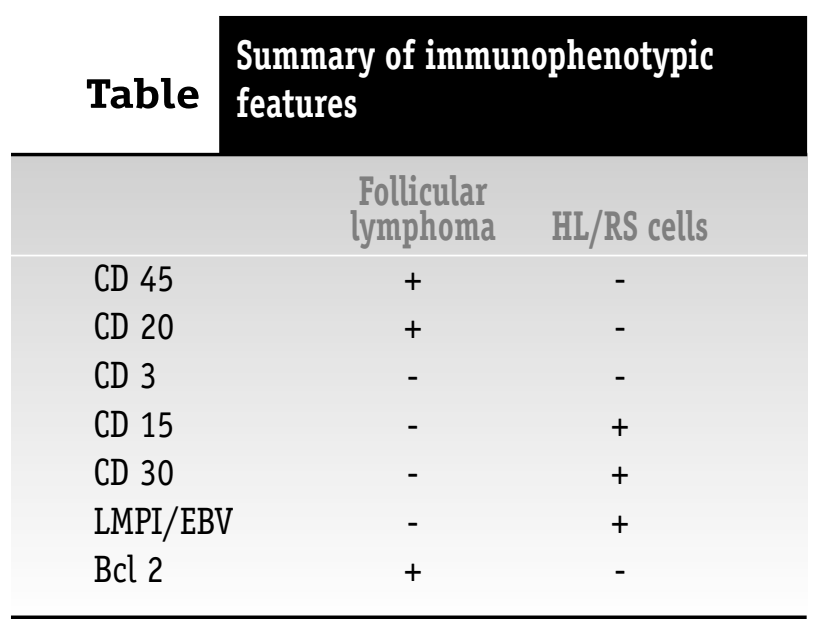

HL: Hodgkin's lymphoma; RS: Reed-Sternberg.

\section{Discussion}

In the present report the authors describe a wellcharacterised composite lymphoma involving the spleen and lymph node composed of a low-grade NHL and a classical $\mathrm{HL}$. The histological features and the immunological profile were consistent with the diagnosis of follicular non-Hodgkin's lymphoma and mixed-cellularity Hodgkin's lymphoma.

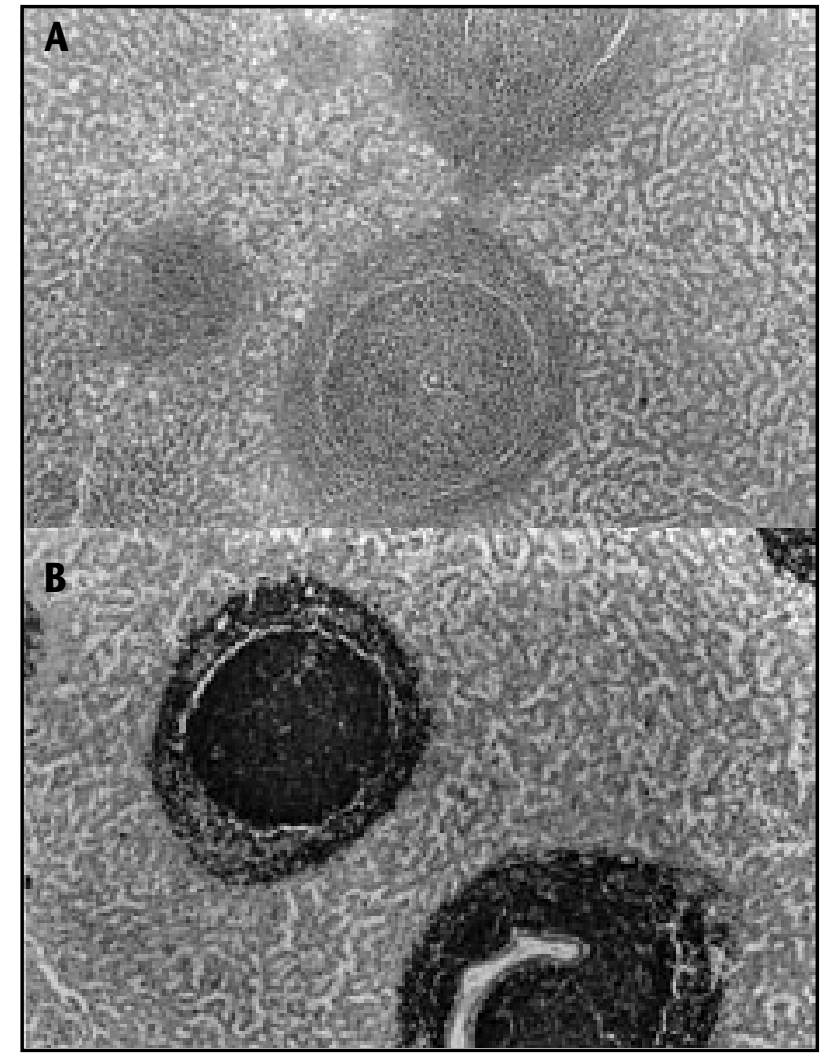

Figure 3 - A: Microscopic section of liver showing infiltration of portal space by small cell lymphoma, similar to that seen in the white pulp of the spleen (H\&E 100 x). B: Small lymphocytes of liver expressing CD 20 (100x)

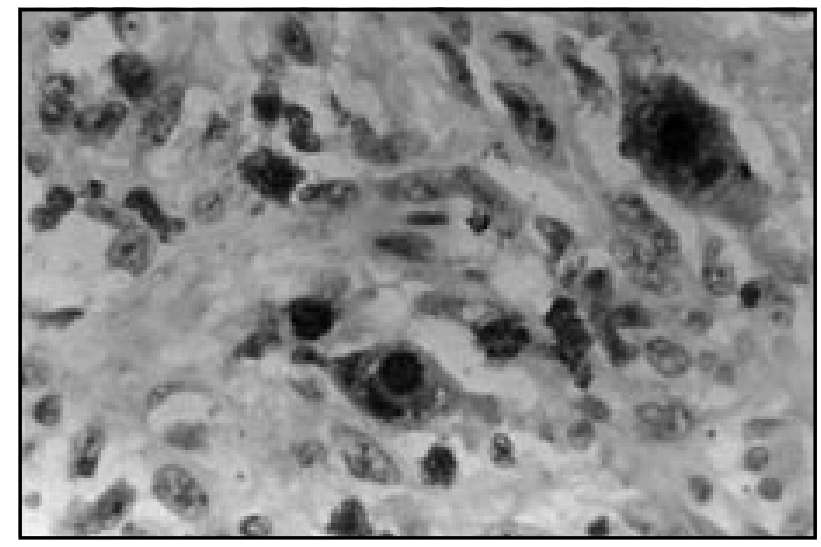

Figure 4 - Hodgkin's lymphoma CD 15 (+) RS cells (400x)

Composite lymphoma is rare and is usually described in lymph nodes $(1,2,4,11)$. The concurrent involvement of the spleen has been rarely reported. To our knowledge, this is the fifth report in the English language literature of a composite lymphoma involving the spleen and presenting prominent splenomegaly. In the previous reported cases the simultaneous occurrence of lymphocyte-predominance $\mathrm{HL} /$ large-cell NHL and lymphoplasmacytoid/large-cell NHL was presented $(8,10,11,12)$. 
Recent studies using different techniques have focused on identifying a common clonal origin for both disorders ${ }^{(1,11)}$. Molecular investigations strongly suggest that a common B-cell precursor located in the germinal center gave rise to both $\mathrm{HL}$ and NHL. As Hodgkin and Reed-Sternberg cells are clonal and originated from germinal center B-cell precursor in most instances ${ }^{(9)}$, it is reasonable to suppose that the occurrence of B-cell lymphoma concurrent with $\mathrm{HL}$ may represent divergent differentiation of the same oncogenic process.
In this paper the authors showed an unusual case of composite lymphoma involving the spleen and lymph node, confirmed by immunohistochemistry. The number of cases reported is too small for a meaningful analysis and conclusion about prognosis. However, there is an emerging consensus that the composite lymphoma has the same prognosis of the more aggressive component and that treatment must point to the aggressive component. In our case septicaemia and the consequent patient's premature death prevented any chemotherapeutic approach.

\section{References}

I. BRAUNINGER, A. et al. Identification of common germinal center B-cell precursors in two patients with both Hodgkin's disease and non-Hodgkin's lymphoma. N Engl J Med, v. 340, p. 1239-47, 1999.

2. DELABIE, J. et al. Concurrent lymphocyte predominance Hodgkin's disease and T-cell lymphoma: a report of three cases. Am J Sur Pathol, v. 20, p. 355-62, 1996

3. GONZALEZ, C. L. et al. Composite lymphoma: a clinicopathologic analysis of nine patients with Hodgkin's disease and B-cell non-Hodgkin's lymphoma. Am J Clin Pathol, v. 96, p. $8|-9,199|$.

4. GREINER, T. et al. Nodular lymphocyte-predominant Hodgkin's disease associated with large-cell lymphoma: analysis of lg gene rearrangements by $\mathrm{V}-\mathrm{J}$ polymerase chain reaction. Blood v. 88, p. 657-66, 1996

5. HANSMANN, C. H. et al. Morphological and immunohistochemical investigation of non-Hodgkin's lymphoma combined with Hodgkin's disease. Histopathology, v. I5, p. 35-48, 1989.

6. HARRIS, N. L. The relationship between Hodgkin's disease and non-Hodgkin's lymphoma. Semin Diagn Pathol, v. 9, p. 30410, 1992.
7. JAFFE, E. S. et al. The relationship of Hodgkin's disease and nonHodgkin's lymphoma: lessons learned from composite and sequential malignancies. Semin Diagn Pathol, v. 9, p. 297-303, 1992.

8. KIM, H. et al. Composite lymphoma. Cancer, v. 40, p. 959-76, 1977.

9. MARAFIOTI,T. et al. Hodgkin's and Reed-Sternberg cells represent an expansion of a single clone originating from a germinal center $\mathrm{B}$ cell with functional immunoglobulin gene rearrangements but defective immunoglobulin transcription. Blood, v. 95, p. 1443-50, 2000.

10. MITTAL, B. B.; NALESNIK, M. Composite lymphoma (Hodgkin's and non-Hodgkin's) of the spleen in a previous untreated patient. Acta Haematol, v. 76, p. 29-32, 1986.

II. PESCARMONA, E. et al. Composite lymphoma, lymphoplasmacytoid and diffuse large B-cell lymphoma of the spleen: molecular-genetic evidence of a common clonal origin. Virchows Arch, v. 435, p. 442-6, 1999.

12. TONER, G. C. et al. Composite lymphoma. Am J Clin Pathol, v. 86, p. 375-8, 1986

13. WARNKE, R. A. et al. Tumors of the lymph nodes and spleen: Atlas of Tumor Pathology. Washington, DC: Armed Forces Institute of Pathology, 1995. p. 329-339.

\section{Mailing address}

Maria do Patrocinio Ferreira Grangeiro Departamento de Patologia e Medicina Legal Faculdade de Medicina - Universisade Federal do Ceará

Rua Monsenhor Furtado S/N - Rodolfo Teófilo CEP 60441-750 - Fortaleza-CE Fax: (55) (85) 288-8316

e-mail: mariapfg@uol.com.br 